\title{
О формировании
}

\section{междисциплинарной концепции антикоррупционного комплаенса в Российской Федерации}

\section{凡目 ю.п. Гармаев}

Профессор, кафедра уголовного процесса и криминалистики Бурятского государственного университета им. Доржи Банзарова, доктор юридических наук. Адрес: 670000, Российская Федерация, Республика Бурятия, Улан-Удэ, ул. Смолина, 24а. E-mail: garmaeff1@mail.ru

\section{凡目 Э.А. Иванов}

Профессор, департамент международного права факультета права Национального исследовательского университета «Высшая школа экономики», доктор юридических наук. Адрес: 101000, Российская Федерация, Москва, Мясницкая ул., 20. E-mail: eaivanov@hse.ru

\section{目 С.А. Маркунцов}

Профессор, департамент систем судопроизводства и уголовного права факультета права Национального исследовательского университета «Высшая школа экономики», доктор юридических наук. Адрес: 101000, Российская Федерация, Москва, Мясницкая ул., 20. E-mail: smarkuntsov@hse.ru

\section{期 Аннотация}

C началом XXI века в компаниях, ведущих бизнес в различных странах мира, началось активное внедрение антикоррупционного комплаенса. Данный процесс не оставил в стороне и российские, в первую очередь крупные компании. Под их влиянием антикоррупционные политики и процедуры постепенно стали приниматься и компаниями, относящимися к среднему и малому бизнесу. Не умаляя роли антикоррупционного комплаенса как механизма защиты компаний от коррупционных преступлений и правонарушений, авторы отмечают, что многие крупнейшие международные компании, вкладывающие огромные ресурсы в создание комплаенс-программ, их руководители и сотрудники оказываются вовлечены в совершение коррупционных деяний и подвергаются уголовному преследованию. На основании исследования авторы приходят к выводу, что антикоррупционный комплаенс не должен сводиться к набору управленческих процессов и формальных стандартов. Необходимо содержательное наполнение антикоррупционных комплаенс-программ и обучение сотрудников компаний, нацеленное на предотвращение коррупционных деяний. В статье выдвигается и обосновывается идея создания междисциплинарной концепции антикоррупционного комплаенса в России, основанной на использовании достижений наук международного права, уголовного права, криминалистики и оперативно-розыскной деятельности. Авторами предложено собственное определение антикоррупционного комплаенса, дана его 
общая характеристика, рассмотрены причины внедрения в корпоративные практики. Проанализированы особенности правового регулирования и тенденции внедрения антикоррупционного комплаенса в России. Предпринята попытка институционализации понятийного аппарата, таких взаимосвязанных в контексте формируемой концепции научных категорий, как коррупционное преступление, преступление коррупционной направленности, коррупционный риск. Междисциплинарная концепция антикоррупционного комплаенса должна лечь в основу стандартов и рекомендаций для российских компаний, корпоративных политик и процедур, методических рекомендаций для судей и сотрудников правоохранительных органов, а также программ обучения и повышения квалификации по вопросам антикоррупционного комплаенса. Концепция может также использоваться для развития антикоррупционного сотрудничества в рамках БРИКС и Евразийского экономического союза.

\section{O-冒 Ключевые слова}

коррупция; антикоррупционное просвещение; антикоррупционные практики; антикоррупционный комплаенс; защита от незаконного обвинения; корпоративный сектор; предупреждение коррупции.

Для цитирования: Гармаев Ю.П., Иванов Э.А., Маркунцов С.А. О формировании антикоррупционного комплаенса в Российской Федерации // Право. Журнал Высшей школы экономики. 2020. № 4. С. 106-128.

УдК: $341 ; 343$

DOI: $10.17323 / 2072-8166.2020 .4 .106 .128$

\section{Введение}

Коррупция - явление, затрагивающее различные сферы общественной жизни и тесно связанное с другими видами преступной деятельности. При разработке Конвенции ООН против коррупции (2003), являющейся основным универсальным международным договором в данной сфере, государства отказались от идеи сформулировать общепризнанное определение коррупции и включили в Конвенцию перечень коррупционных преступлений, которые должны войти в национальное уголовное законодательство государств-участников. В наиболее общем виде под коррупцией понимается злоупотребление доверенной властью для извлечения личной выгоды ${ }^{1}$.

Россия придерживается широкого подхода к определению коррупции, включая в него преступления, совершаемые как в публичной, так и в частной сфере. В ст. 1 Федерального закона от 25.12.2008 № 273-Ф3 «О противодействии коррупции» коррупция определяется как:

1 Transparency International. What is corruption? Available at: https://www.transparency.org/ en/what-is-corruption (дата обращения: 29.07.2020) 
злоупотребление служебным положением, дача взятки, получение взятки, злоупотребление полномочиями, коммерческий подкуп либо иное незаконное использование физическим лицом своего должностного положения вопреки законным интересам общества и государства в целях получения выгоды в виде денег, ценностей, иного имущества или услуг имущественного характера, иных имущественных прав для себя или для третьих лиц либо незаконное предоставление такой выгоды указанному лицу другими физическими лицами;

совершение деяний, указанных в подпункте «а» настоящего пункта, от имени или в интересах юридического лица.

Большой вклад в изучение проблемы коррупции в России внесли В.В. Астанин, О.Я. Баев, Ю.В. Голик, А.Ю. Головин, И.А. Дамм, А.И. Долгова, А.М. Иванов, С.М. Иншаков, Н.А. Лопашенко, В.А. Номоконов, Б.А. Осипов, Е.В. Смахтин, Н.В. Сторчилова, А.Л. Репецкая, А.Н. Халиков, Н. В. Щедрин. Авторам удалось проанализировать различные формы коррупции в системе государственной и муниципальной службы, разработать целый ряд мер, направленных на предотвращение коррупции, рекомендации по выявлению, пресечению и расследованию коррупционных преступлений. Среди зарубежных исследований отметим работы М. Джонстона, Р. Клитгарда, М. Леви, Н. Пассаса, Л. Холмса.

Современная коррупция развивается под влиянием различных факторов общественной жизни (формирование глобальных рынков товаров и услуг, отсутствие границ в отдельных регионах мира, внедрение новых технологий передачи информации, управления и ведения бизнеса, появление криптовалют и новых платежных систем). Можно выделить ряд отличительных особенностей современной коррупции:

вовлечение в коррупционные отношения должностных лиц различного уровня, вплоть до руководителей государств [Moretti D., 2018: 2-3]2;

участие коррумпированных должностных лиц в бизнесе в качестве постоянных «деловых партнеров»;

использование для получения крупных коррупционных выплат сложных корпоративных структур;

планирование получения коррупционных выплат параллельно с последующей легализацией преступных доходов;

использование в расчетах современных технологий, криптовалют и новых платежных систем³.

2 Экс-президента Южной Кореи приговорили к 24 годам тюрьмы. Available at: URL: https://rg.ru/2018/04/06/sud-vynes-prigovor-eks-prezidentu-iuzhnoj-korei-pak-kyn-he.html (дата обращения: 27.07.2020)

${ }^{3}$ FATF. Guidance for a risk-based approach to virtual assets and virtual asset service providers. 2019. Available at: https://www.fatf-gafi.org/media/fatf/documents/recommendations/RBA-VAVASPs.pdf (дата обращения: 27.07.2020) 
Наряду с коррупцией в публичной сфере получила распространение и коррупция в сфере бизнеса, основным проявлением которой является коммерческий подкуп. В данном случае функции «коррумпированных должностных лиц» берут на себя менеджеры компаний-партнеров. Коррупция в сфере бизнеса проявляется при выборе подрядчиков и поставщиков в рамках тендерных процедур, при размещении рекламы, нередко приводит к утечке информации, составляющей коммерческую тайну. Решения, принимаемые менеджерами в результате коммерческого подкупа, наносят существенный экономический, а в ряде случаев - и репутационный ущерб компаниям.

Негативное влияние коррупции на общество и государство трудно переоценить. Коррупция убивает доверие граждан к органам государственной власти, стимулирует ведение бизнеса в теневом секторе и уклонение от уплаты налогов. Исчезает возможность конструктивного диалога между бизнесом и властью, выработки эффективных законодательных и управленческих решений.

На протяжении многих лет система противодействия коррупции как в России, так и в зарубежных странах была нацелена прежде всего на предотвращение коррупционных преступлений и правонарушений государственных и муниципальных служащих. Вместе с тем очевидно, что в коррупционных отношениях участвуют как минимум две стороны: государственные и муниципальные служащие, оказывающие коррупционные «услуги», и коммерческие и некоммерческие организации, являющиеся их «клиентами». Коррупция в форме коммерческого подкупа существует и в частном секторе, нанося значительный ущерб добросовестным владельцам компаний. Соответственно система противодействия коррупции должна охватывать всех субъектов, которые могут быть вовлечены в коррупционные отношения. На основе такого понимания в компаниях по всему миру постепенно происходит внедрение антикоррупционного комплаенса в качестве механизма защиты компаний от коррупционных преступлений и правонарушений.

Настоящая статья является результатом совместного исследования авторов, направленного на формирование междисциплинарной научной концепции антикоррупционного комплаенса в России. Использовались диалектический, формально-логический, сравнительно-правовой методы и методы статистического анализа и моделирования.

\section{1. Антикоррупционный комплаенс В Российской Федерации: современное состояние и перспективы развития}

Термин «комплаенс» возник в правовой системе «общего права». Буквальный перевод на русский язык слова «комплаенс» как «соответствие чему-ли- 
бо» не приводит к полному пониманию сути данного термина, получившего широкое распространение. В последние десятилетия сфера комплаенса неуклонно расширяется, охватывая все новые направления деятельности компаний и виды правоотношений. Антикоррупционный комплаенс является одним из видов комплаенса наряду с антимонопольным, налоговым, экологическим и рядом других.

Можно дать следующее базовое определение антикоррупционного комплаенса: это процесс управления, который позволяет определять применимые правовые нормы, выявлять и оценивать коррупционные риски, создавать локальные нормы организации с учетом этических принципов, а затем принимать меры, направленные на соблюдение организацией и взаимодействующими с ней лицами правовых норм, локальных норм организации и профилактику коррупционных рисков. Основными внутренними документами организации, регулирующими разработку и внедрение системы антикоррупционного комплаенса, являются кодекс деловой этики и антикоррупционная комплаенс-программа.

Можно выделить следующие цели внедрения антикоррупционного комплаенса в компаниях:

обеспечение ведения бизнеса в соответствии с антикоррупционными требованиями законодательства, этическими принципами, ценностями и локальными нормами компании;

предотвращение вовлечения компании, филиалов, представительств, дочерних и зависимых компаний, сотрудников и контрагентов компании в совершение коррупционных преступлений и правонарушений;

защита компании от коррупционных деяний, например, от вымогательства взятки.

Наряду с компаниями антикоррупционный комплаенс постепенно внедряют и некоммерческие организации, в частности действующие в гуманитарной сфере.

По своей природе и структуре антикоррупционный комплаенс близок к внутреннему контролю в целях противодействия легализации (отмыванию) доходов, полученных преступным путем, и финансированию терроризма. При этом подходы законодателей к регулированию данных видов комплаенса принципиально отличаются. Принятие мер по противодействию легализации (отмыванию) доходов, полученных преступным путем, и финансированию терроризма, является обязательным для определенных категорий кредитных и иных организаций. Неисполнение этой обязанности может повлечь за собой отзыв лицензии на соответствующий вид деятельности или иные меры воздействия со стороны надзорных органов.

Антикоррупционный комплаенс в большинстве стран не является обязательным. Требования отечественного законодательства являются одним 
из редких исключений. Принятие организациями мер по предупреждению коррупции предусмотрено ст. 13.3 Федерального закона «О противодействии коррупции», вступившей в силу 01.01.2013․ Несмотря на обязательный характер ст. 13.3, ответственность за ее неисполнение отсутствует. В этой связи важную роль в продвижении внедрения антикоррупционного комплаенса выполняет прокурорский надзор за соблюдением требований Федерального закона «О противодействии коррупции». Органы прокуратуры регулярно проводят проверки соблюдения организациями требований ст. 13.3. В соответствии с ч. 3 ст. 22 Федерального закона от 17.01.1992 № 2202-1 «О прокуратуре Российской Федерации» прокурор или его заместитель вносит представление об устранении нарушений закона, выявленных в ходе проверки ${ }^{5}$. Невыполнение законных требований прокурора влечет за собой административную ответственность по ст. 17.7 Кодекса Российской Федерации об административных правонарушениях (далее - КоАП). Статья предусматривает санкции: наложение административного штрафа на должностных лиц - от 2 тысяч до 3 тысяч рублей либо дисквалификацию на срок от шести месяцев до одного года; на юридических лиц - от 50 тысяч до 100 тысяч рублей либо административное приостановление деятельности на срок до 90 суток. Административная ответственность за невыполнение законных требований прокурора фактически компенсирует отсутствие мер ответственности непосредственно за неисполнение требований ст. 13.3 Федерального закона «О противодействии коррупции».

На практике внедрение антикоррупционного комплаенса российскими компаниями обусловлено различными причинами, делятся на несколько групп. В первую группу входят субъективные причины, личная позиция руководителей и владельцев компаний в отношении неприемлемости коррупции как метода ведения бизнеса. Такая позиция может быть обусловлена этическими принципами и ценностями руководителей и владельцев, заботой о деловой репутации компании. Ко второй группе можно отнести сугубо прагматичное стремление снизить риски коррупции на уровне менеджеров среднего звена и сотрудников, предотвратить возможный экономический ущерб и увеличить прибыль от ведения бизнеса.

К третьей группе относятся юридические причины. Бизнесмены осознают риск личной уголовной ответственности и административной ответственности юридических лиц и стремятся предотвратить вовлечение

${ }^{4}$ Федеральный закон от 03.12.2012 № 231-Ф3 «О внесении изменений в отдельные законодательные акты Российской Федерации в связи с принятием Федерального закона «О контроле за соответствием расходов лиц, замещающих государственные должности, и иных лиц их доходам» // СЗ РФ. 2012. № 50 (ч. 4). Ст. 6954.

5 Федеральный закон от 17.01. 1992 № 2202-1 «О прокуратуре Российской Федерации» // СЗ РФ. 1995. № 47. Ст. 4472. 
компаний в совершение коррупционных деяний. Некоторые компании, несмотря на отсутствие в законе мер ответственности, стремятся выполнять требования ст. 13.3 Федерального закона «О противодействии коррупции». В ст. 19.28 КоАП не предусмотрена обязанность судей учитывать наличие антикоррупционной комплаенс-программы при решении вопроса о привлечении юридических лиц к ответственности и назначении наказания. Судебная практика по данному вопросу неоднозначна, однако есть примеры, когда судьи снижали размер штрафа с учетом принимавшихся компаниями антикоррупционных мер 6 .

К данной группе относятся и риски применения иностранного антикоррупционного законодательства, имеющего экстерриториальное действие. Еще до принятия ст. 13.3 крупные российские компании, особенно работающие на зарубежных рынках, принимали кодексы деловой этики и антикоррупционные комплаенс-программы с учетом рисков применения Закона США «О борьбе с практикой коррупции за рубежом» $(1977)^{7}$ и Акта Великобритании «О взяточничестве» $(2010)^{8}$. К более узкому кругу иностранных компаний может применяться и Закон Франции о прозрачности, борьбе с коррупцией и модернизации экономической жизни (2016) (Sapin II) ${ }^{9}$. В ряде стран законодательство и решения высших судебных органов допускают возможность существенного снижения штрафов при наличии эффективной антикоррупционной комплаенс-программы (Бразилия, ФРГ, США). Акт Великобритании «О взяточничестве» гласит, что такая программа может позволить компании полностью избежать уголовной ответственности.

Четвертая группа включает рыночные причины. Стремясь снизить риски вовлечения в совершение преступлений коррупционной направленности, компании, особенно крупные, занимающие лидирующие позиции на рынке, требуют от партнеров внедрить антикоррупционные меры. Соответствующие положения могут включаться в антикоррупционную оговорку, являющуюся неотъемлемой частью договора.

В пятую группу входят требования, связанные с участием в коллективных антикоррупционных инициативах бизнеса либо в совместных инициативах государства и бизнеса. Коллективные антикоррупционные инициативы получили распространение в более чем 200 странах мира.

${ }^{6}$ Бейкер Макензи. Отчет о результатах исследования практики применения ст. 19.28 КоАП РФ. Available at: URL: https://www.bakermckenzie.com/ru/insight/publications/2019/11/ corporate-anti-corruption-enforcement (дата обращения: 26.07.2020)

7 Foreign Corrupt Practices Act of 1977, PL 95-213, Title 1; 91 Stat 1494, Dec 19, 1977.

${ }^{8}$ UK Bribery Act of 2010. Available at: http://www.legislation.gov.uk/ukpga/2010/23/contents (дата обращения: 30.07.2020)

${ }^{9}$ LOI n ${ }^{\circ}$ 2016-1691 du 9 décembre 2016 relative à la transparence, à la lutte contre la corruption et à la modernisation de la vie économique (1). Available at: www.legifrance.gouv.fr/eli/ loi/2016/12/9/2016-1691/jo/texte (дата обращения: 30.07.2020) 
Правовое регулирование антикоррупционного комплаенса существенно отличается от регулирования внутреннего контроля в целях противодействия легализации преступных доходов и финансированию терроризма.

В сфере антикоррупционного комплаенса существует более 30 международных стандартов и руководств, опубликованных международными межправительственными и неправительственными организациями, международными предпринимательскими объединениями и ведущими международными консультантами. Ни один из этих стандартов и руководств не получил всеобщего признания, сопоставимого по уровню с признанием Рекомендаций ФАТФ. Какая-либо иерархия стандартов и руководств также отсутствует. Существуют руководства, посвященные антикоррупционной комплаенс-программе в целом или ее отдельным разделам. Соответственно, компании могут использовать при внедрении антикоррупционного комплаенса любые стандарты и руководства. На национальном уровне рекомендации для организаций по разработке и внедрению антикоррупционных комплаенс-программ приняты только в восьми государствах ${ }^{10}$. Некоторые государства рекомендуют компаниям использовать стандарт ISO $37001^{11}$.

В связи с отсутствием общепризнанного стандарта или руководства на международном уровне, а также национальных стандартов и руководств в большинстве стран, многие компании используют при разработке антикоррупционных комплаенс-программ иностранные руководства и рекомендации. Особое внимание уделяется рекомендациям регуляторов Великобритании и США, поскольку антикоррупционное законодательство этих стран имеет экстерриториальное действие. Компании, относящиеся к малому и среднему бизнесу, также учитывают антикоррупционные комплаенс-программы крупных компаний, являющихся их партнерами.

В России регуляторы стремятся оказать компаниям необходимую методическую помощь во внедрении антикоррупционного комплаенса. Министерством труда и социальной защиты Российской Федерации 08.11.2013 были опубликованы Методические рекомендации о разработке и принятию организациями мер по предупреждению и противодействию коррупции, получившие в 2019 г. дальнейшее развитие в рекомендациях и письмах по вопросам оценки коррупционных рисков и закреплению обязанностей работников, связанных с предупреждением коррупции.

Заметную роль в продвижении антикоррупционного комплаенса играет Центральный Банк России. Концепция организации системы внутреннего контроля для некредитных финансовых организаций, опубликованная Банком 31.10.2017, предусматривает в числе основных задач органов внутрен-

10 Бразилия, Великобритания, Италия, Перу, США, Россия, Украина, Франция.

${ }_{11}$ Singapore Adopts ISO 37001 (FCPA Blog, 18 April 2017). Available at: www.fcpablog.com/ blog/2017/4/18/kristy-grant-hart-singapore-adopts-iso-37001.html (дата обращения: 29.07.2020) 
него контроля разработку внутренних документов, направленных на противодействие коммерческому подкупу и коррупции ${ }^{12}$. Несмотря на принятие ст. 13.3 Федерального закона «О противодействии коррупции», внедрение антикоррупционного комплаенса в России протекает медленно.

Важно отметить, что к ответственности за нарушение требований антикоррупционного законодательства, в частности, законодательства Великобритании и США, привлекаются крупнейшие международные компании, которые имели или по крайней мере должны были иметь разработанные антикоррупционные комплаенс-программы и необходимые для их функционирования финансовые ресурсы. На наш взгляд, это не означает, что в среднем и малом бизнесе дела обстоят значительно лучше, и компании имеют более эффективные антикоррупционные комплаенс-программы. Скорее, регуляторы и правоохранительные органы уделяют основное внимание крупнейшим компаниям, а средний и малый бизнес пока остается вне их поля зрения.

Почему же внедрение компаниями антикоррупционных комплаенс-программ часто не дают нужного результата? С одной стороны, очевидно, что ни одна государственная, и тем более корпоративная, система мер, направленных на предупреждение преступности, не может дать стопроцентного результата. С другой стороны, целесообразно серьезное изучение вопроса о возможности новых концептуальных подходов к созданию и функционированию системы антикоррупционного комплаенса.

Одной из основных причин ситуации является понимание антикоррупционного комплаенса во многих компаниях как еще одного набора бюрократических документов и процедур, требующего регулярных расходов и не дающего эффекта. Документам и процедурам придается необходимая форма, не наполненная содержанием. Антикоррупционный комплаенс рассматривается как один из элементов корпоративного управления. При этом роль комплаенса как механизма предупреждения коррупционных преступлений отходит на второй план.

Антикоррупционные комплаенс-программы международных компаний далеко не всегда адаптируются к реалиям той или иной страны и учитывают специфику коррупционных рисков и схем коррупционных преступлений. Проведенное в 2017 г. исследование показало, что 55\% международных компаний применяют свои глобальные комплаенс-программы по всему миру, не внося изменений, учитывающих местную специфику ${ }^{13}$. Компании пере-

12 Концепция организации системы внутреннего контроля для некредитных финансовых организаций. Available at: URL: www.cbr.ru/content/document/file/27671/inf_note_oct_3117.pdf (дата обращения: 23.07.2020)

${ }^{13}$ Can companies really adopt a single global anti-corruption policy. Available at: www.fcpablog. com/blog/2017/6/28/john-bray-can-companies-really-adopt-a-single-global-anti-co.html (дата обращения: 26.07.2020) 
водят глобальные комплаенс-программы на другие языки и ожидают, что программы сработают так же, как в странах регистрации компаний. В результате через некоторое время компания сталкивается с неприятными сюрпризами. Нередко выясняется, что описанные в программе политики и процедуры не учитывают коррупционные риски страны, характерные способы совершения коррупционных преступлений и правонарушений. Программа оказывается неработающей и если она не учитывает базовые ценности и культурные традиции граждан.

Документы и процедуры нередко не имеют необходимого подкрепления в виде методик предотвращения и выявления коррупционных преступлений и правонарушений. Серьезной проблемой также является недостаток у сотрудников подразделений комплаенс необходимых знаний и навыков. На протяжении многих лет подготовка специалистов для подразделений комплаенс на системной основе не осуществлялась. Сотрудники приходили на эту работу с неодинаковым опытом и с разными пробелами в подготовке. Знание той или иной сферы бизнеса, полученное в ходе работы в клиентских или финансовых подразделениях компаний, совершенно не означало, что сотрудник сможет выявить завуалированную преступную схему. Бывшие сотрудники правоохранительных органов, приходя в подразделения комплаенс, наоборот, нередко сталкивались со трудностями в понимании специфики бизнеса, например, на рынке ценных бумаг. Для эффективной работы сотрудник, отвечающий за антикоррупционный комплаенс, должен обладать уникальным набором знаний и навыков, включающим понимание бизнеса, знания в финансовой сфере, знания в области уголовного права, криминологии, криминалистики, психологии. В крупных компаниях могут потребоваться и знания в сфере международного права и иностранного законодательства.

Необходимо также отметить, что сотрудники правоохранительных органов, со своей стороны, далеко не всегда знакомы с функциями подразделений комплаенс и готовы к организации взаимодействия в целях профилактики, выявления и пресечения коррупционных деяний.

Антикоррупционный комплаенс должен стать реальным механизмом защиты интересов компаний от коррупционных правонарушений и преступлений и способствовать проведению государственной антикоррупционной политики. Для этого антикоррупционный комплаенс должен стать не только красивым описанием бизнес-процессов и соответствующих превентивных мер, но вобрать в себя огромный опыт предупреждения и выявления преступлений и правонарушений коррупционной направленности, накопленный в криминологии, криминалистике, науке уголовного права, уголовного процесса и оперативно-розыскной деятельности. 


\section{2. Уголовно-правовые и криминологические аспекты антикоррупционного комплаенса}

В контексте использования наработок уголовного права и криминологии в части формирования концепции антикоррупционного комплаенса в России складывается неоднозначная ситуация. С одной стороны, исходя из предложенного ранее определения антикоррупционного комплаенса можно сделать вывод, что основная его сущность заключается в профилактике (предупреждении) коррупционных рисков. Аналогичной позиции придерживается и ученые. В частности, Ю.А. Крохина, проанализировав различные подходы к пониманию и сущности антикоррупционного комплаенса, приходит к выводу, что комплаенс является, прежде всего, мерой по предупреждению и предотвращению правонарушений в сфере финансового (бюджетного, налогового) и корпоративного законодательства [Крохина Ю.А., 2019: 36].

В п. 2 ст. 1 Федерального закона «О противодействии коррупции» используются понятия предупреждения коррупции и предупреждения коррупционных правонарушений. В частности, указывается, что «противодействие коррупции - деятельность федеральных органов государственной власти, органов государственной власти субъектов РФ, органов местного самоуправления, институтов гражданского общества, организаций и физических лиц в пределах их полномочий: а) по предупреждению коррупции, в том числе по выявлению и последующему устранению причин коррупции (профилактика коррупции); б) по выявлению, предупреждению, пресечению, раскрытию и расследованию коррупционных правонарушений (борьба с коррупцией); в) по минимизации и (или) ликвидации последствий коррупционных правонарушений» ${ }^{14}$.

Вероятно, ставя на первое место в определении противодействия коррупции ее профилактику, законодатель намеревался подчеркнуть не только первичность указанных мер в их временной последовательности, но также их важность в контексте предупреждения коррупции. Обосновано и упоминание в пп. «б» п. 2 ст. 1 именно коррупционных правонарушений как единого понятия, объединяющего как преступления, так и проступки. Данное обстоятельство является обоснованным также в контексте единства деятельности по предупреждению правонарушений и преступлений: в доктрине разрабатываются универсальные теории предупреждения преступлений (преступности) $)^{15}$, при подготовке специалистов в области право-

${ }^{14}$ СЗ РФ. 2008. № 52 (ч. І). Ст. 6228.

15 В частности, А.И. Марцев и С.В. Максимов обосновывают необходимость того, чтобы общее предупреждение преступлений вошло составной частью в единую систему социально-правовой профилактики правонарушений на всех уровнях, что, в свою очередь, 
охранительной деятельности происходит комплексное изучение указанного явления [Кикоть В.Я., Лебедев С.Я., Румянцев Н.В., 2015]. Вместе с тем из текста (определения противодействия коррупции. - Авт.) ускользнула конечная цель, ради которой принимаются меры по раскрытию и расследованию коррупционных правонарушений, - адекватное воздаяние за содеянное. Любое противодействие предполагает и адекватную государственную реакцию в виде применения строго регламентированных санкций [Наумов С.Ю., Чаннов С.Е., 2009: 28-29].

Интересно в этом контексте, что предупредительная (профилактическая - такое название допускается) задача уголовного права в том или ином виде выделяется практически всеми учеными. Большинство ученых в рамках задачи предупреждения преступлений выделяет общую и частную (специальную) превенции. Однако, например, Л.Д. Гаухман считал, что такой аспект предупредительной задачи уголовного права, как частная превенция, прямо не вытекает из положений ч. 1 ст. 2 УК РФ [Гаухман Л.Д., Колодкин Л.М., Максимов С.В., 1999: 8]. Ф.Р. Сундуров справедливо отмечает, что эффект уголовного права в плане общего предупреждения преступлений весьма трудно вычислить, тем более, определить его в количественных характеристиках [Сундуров Ф.Р., Тарханов И.А., 2009: 24]. В.Ф. Щепельков, указывая, что в соответствии с ч. 1 ст. 2 УК РФ задачей УК является предупреждение преступлений, задается вопросом: «Каков критерий оценки закона на его соответствие данному критерию?». Он же отмечает, что ответ на этот вопрос весьма проблематичен [Щепельков В.Ф., 2003: 90-91]. В науке существуют диаметрально противоположные мнения в оценке эффективности общего предупреждения преступлений. В частности, А.И. Марцев и С.В. Максимов пришли к выводу о существенном влиянии общего предупреждения на ограничение распространенности отдельных видов преступлений [Марцев А.И., Максимов С.В., 1989: 159]. С другой стороны, М.М. Бабаев указывает на явно немощную силу общепредупредительного влияния норм уголовного права [Бабаев М.М., 2018: 107].

Предупредительная (превентивная - в трактовке А.И. Бойцова) функция уголовного права выделяется не всеми учеными, так как часто рассматривается в качестве составной части регулятивно-охранительного воздействия. По мнению Ю.Е. Пудовочкина, в ряду социальных функций отрасли первостепенное значение имеет функция предупреждения преступлений (предупредительная функция), непосредственно указанная в ч. 1 ст. 2 УК

выдвигает задачу создания универсальной теории эффективности общего предупреждения преступлении [Марцев А.И., Максимов С.В., 1989: 160]. По мнению Н.В. Щедрина, криминологическая теория предупреждения преступности - это учение о совокупности всех законных видов, форм, способов, средств и методов контроля над преступностью независимо от того, какой отраслью права они предусмотрены [Щедрин Н.В., 1999: 6]. 
РФ [Пудовочкин Ю.Е., 2008: 246]. Выделение этой функции часто прямо обуславливается и связывается с содержанием одноименной задачи уголовного права и трактуется исходя из содержания последней. Функции - это средства реализации задач, а задачи одновременно являются результатом, который достижим при реализации функций. Зачастую задачами во многом определяется интенсивность и специфика функций, при определенных условиях возможна и обратная ситуация.

Во многом базируясь на понимании предупреждения преступлений как функции уголовного права ${ }^{16}$, соответствующий институт является одним из базовых элементов в предмете рассмотрения криминологии. Еще в начале $\mathrm{XX}$ в. Г. Ашаффенбург утверждал, что «для социологов и криминалистов я не знаю иной более высокой задачи, как предупреждение преступлений» [Ашаффенбург Г., 2001: 180] ${ }^{17}$. Напомним, что при определении предмета криминологии в рамках первого учебника по этой учебной дисциплине, изданном в СССР, А.А. Герцензон писал: основываясь на изучении преступности как социального явления, причин преступности в целом, отдельных видов преступлений, личности преступников, практики борьбы с преступностью, советская криминология разрабатывает систему предупредительных мер (рекомендаций), направленных на искоренение преступности и порождающих ее причин [Герцензон А.А., Карпец И.И., Кудрявцев В.Н., 1966: 9]. Впрочем, развитие криминологии не исключило и не исключает исследования соответствующего явления в контексте науки уголовного права. По мнению А.И. Марцева и С.В. Максимова, развитие социологии уголовного права, получение сведений о том, что удерживающим от совершения преступлений воздействием обладает не только угроза применения уголовного наказания, но и само существование уголовно-правового запрета, а также соответствующая правоприменительная практика закономерно привели к тому, что понятие общего предупреждения обогатилось новым содержанием. Ученые отмечали, что величина удерживающего эффекта, которым обладает уголовно-правовой запрет, в большей степени зависит от неотвратимости ответственности, основанной на юридической практике, а не от ее суровости. Значение общего предупреждения преступлений определяется еще и тем, что оно связывает в единую систему законодательство, практику его применения и сознание людей, испытывающих их воздействие [Марцев А.И., Максимов С.В., 1989: 4].

16 Так, обосновывая взаимосвязь уголовной ответственности и предупреждения преступлений, А.И. Марцев указывал, что общее предупреждение, как известно, в основе своей существует как функция, как комплекс государственно-правовых мероприятий, направленных на удержание граждан от совершения преступлений [Марцев А.И., 1980: 35].

17 Работа Г. Ашаффенбурга вышла первым изданием в Одессе в 1906 г. 
Вопросы предупреждения преступлений и правонарушений (преступности) входили и входят в предмет науки криминологии и уголовного права, в последнее время внимание к ним значительно возросло вследствие принятия ряда федеральных законов предупредительно-профилактического действия, относимых рядом ученых к криминологическому законодательству [Клейменов М.П., 2017: 181]. Одним из таких законов является упоминающийся выше Федеральный закон «О противодействии коррупции».

Вопросы противодействия коррупции, уголовной ответственности за совершение коррупционных преступлений активно разрабатываются в рамках отечественной науки. Вопросам уголовно-правового противодействия коррупции уделяется весьма пристальное внимание на законодательном уровне. Только за последние примерно четыре года в УК РФ было введено 9 статей, устанавливающих ответственность за преступления коррупционной направленности в их современном понимании ${ }^{18}$. Речь идет о преступлениях, предусмотренных ст. 204.1, 204.2, 291.2, 201.1, 285.4, 200.4-200.6, 210.1 УК РФ. Три из шести предложений, содержащихся в разделе VII «Систематизация и актуализация нормативно-правовой базы по вопросам противодействия коррупции. Устранение пробелов и противоречий в правовом регулировании в области противодействия коррупции» Национального плана противодействия коррупции на 2018-2020 годы ${ }^{19}$, по сути, посвящены совершенствованию уголовно-правового регулирования. В частности, речь идет о предложениях расширения перечня должностных лиц, предусмотренного примечаниями к ст. 285 УК РФ (пп. «а» п. 37), подготовки обзоров судебной практики по уголовным делам (п. 38), установления дополнительных квалифицирующих признаков мелкого взяточничества (пп. «а» п. 39).

Вместе с тем в контексте использования наработок уголовного права и криминологии в части формирования концепции антикоррупционного комплаенса ситуация выглядит менее оптимистично. В частности, в указанном Национальном плане противодействия коррупции не предусмотрено мер актуализации нормативно-правовой базы в сфере антикоррупционного комплаенса. В рамках действующей системы права наряду с понятием «преступления коррупционной направленности», чьи признаки и система обозначены в приложении 23 Указания Генпрокуратуры России №35/11, МВД России №1 от 24.01.2020, активно используется понятие «коррупционные

18 Исходя из перечня преступлений коррупционной направленности, обозначенных в п. 2-4 приложения 23 Указания Генпрокуратуры России № 35/11, МВД России № 1 от 24.01.2020 «О введении в действие перечней статей Уголовного кодекса Российской Федерации, используемых при формировании статистической отчетности» // СПС КонсультантПлюс.

19 Указ Президента РФ от 29.06.2018 № 378 «О Национальном плане противодействия коррупции на 2018-2020 годы» // СЗ РФ. 2018. № 27. Ст. 4038. 
преступления» ${ }^{20}$. Однако вопрос о выделении системы преступлений в сфере антикоррупционного комплаенса вообще пока не ставится.

Отдельные попытки исследования содержательного элемента антикоррупционного комплаенса в уголовно-правовой сфере представляются не вполне удачными. Так, П.С. Яни и Н.В. Прохоров, обосновывая необходимость рассмотрения обозначенной проблемы сквозь призму понятия уголовно-правовых рисков, под содержательным элементом антикоррупционного комплаенса в уголовно-правовой сфере предлагают понимать установление применимых уголовно-правовых норм, предусматривающих как ответственность за коррупционные преступления (исполнителя и иных соучастников, за оконченное и неоконченное преступление и т.д.), так и освобождение от нее, а также обстоятельства, исключающие преступность деяний, содержащих на первый взгляд все признаки составов коррупционных преступлений [Яни П.С., Прохоров Н.В., 2018: 55]. В целом поддерживая идею об использовании при исследовании соответствующей проблематики понятия уголовно-правовых рисков ${ }^{21}$, нецелесообразно вести при этом речь о составах коррупционных преступлений и в целом об ответственности за коррупционные преступления.

Дальнейшая иллюстрация учеными в рамках обозначенной статьи проблемы содержательного элемента антикоррупционного комплаенса в уголовно-правовой сфере на примерах базовых преступлений против порядка управления (получение взятки, дача взятки, мелкое взяточничество, посредничество во взяточничестве), пусть даже и относящихся к преступлениям коррупционной направленности, отнюдь не убеждает в том, что речь идет именно об антикоррупционном комплаенсе, а не в целом о противодействии коррупции. Впрочем, безусловной заслугой ученых является постановка проблемы содержательного элемента антикоррупционного комплаенса в уголовно-правовой сфере.

Таким образом, наработки уголовного права и криминологии в части формирования концепции антикоррупционного комплаенса в России

${ }^{20}$ Речь о них идет, например, в Стратегии национальной безопасности Российской Федерации (п. 43, 46), в Указании Генпрокуратуры России от 14.05.2019, в постановлении Пленума Верховного Суда РФ «О судебной практике по делам о взяточничестве и об иных коррупционных преступлениях». См.: Указ Президента РФ от 31.12.2015 № 683 «О Стратегии национальной безопасности Российской Федерации» // СЗ РФ. 2016. № 1 (ч. II). Ст. 212; Указание Генпрокуратуры России от 14.05.2019 № 341/86 «О порядке работы органов прокуратуры Российской Федерации по привлечению к ответственности юридических лиц, от имени или в интересах которых совершаются коррупционные преступления» // Законность. 2019. № 6; Постановление Пленума Верховного Суда РФ от 09.07.2013 № 24 (ред. от 24.12.2019) «О судебной практике по делам о взяточничестве и об иных коррупционных преступлениях» // Бюллетень Верховного Суда РФ. 2013. № 9.

${ }^{21}$ Именно в контексте следующего их понимания: [Жалинский А.Э., 2008: 242-249]. 
практически не используются. На уровне доктрины не только отсутствует представление о системе преступлений в сфере антикоррупционного комплаенса, но даже не используется соответствующее понятие. Система преступлений в сфере антикоррупционного комплаенса, будучи составной частью системы коррупционных преступлений, отличается от последней как по количественным, так и по качественным характеристикам (например, далеко не все случаи дачи или получения взятки следует относить к комплаенс-преступлениям). Вместе с тем при формировании междисциплинарной концепции антикоррупционного комплаенса исследование системы преступлений в обозначенной сфере должно базироваться на достижениях науки уголовного права и криминологии в части изучения проблем предупреждения преступлений, уголовно-правовых и криминогенных рисков ${ }^{22}$, формирования единого подхода к пониманию коррупционных преступлений (преступлений коррупционной направленности).

\section{3. Криминалистические и оперативно-розыскные аспекты антикоррупционного комплаенса: постановка проблемы}

В контексте обсуждения идеи создания именно междисциплинарной концепции антикоррупционного комплаенса следует отметить практически полное отсутствие на текущий момент исследований, посвященных его криминалистической и оперативно-розыскной содержательной составляющей. Между тем знания, накопленные этими прикладными юридическими науками - ценнейший и пока совершенно невостребованный источник, кладезь полезной информации для содержательной стороны антикоррупционного комплаенса. Однако источник этот вряд ли получится использовать непосредственно. Причина проста. Соответствующие разработки адресованы профессиональным участникам уголовного процесса со стороны обвинения - прежде всего оперативным сотрудникам и следователям ${ }^{23}$. Эти данные подлежат глубокой переработке и адаптации криминалистами-разработчиками, например, для целей подготовки комплаенс-офицеров и профилактических занятий для менеджмента и сотрудников организаций корпоративного сектора.

В контексте создания междисциплинарной концепции антикоррупционного комплаенса, необходимо помимо институционализации понятийного

22 Подробнее об этом см.: [Бабаев М.М., 2018: 104-110]; [Бабаев М.М., Пудовочкин Ю.Е., 2019: 136-148] и др.

${ }_{23}$ См., например: [Баев О.Я., 2009]; [Башмаков И.С., 2007]; [Смахтин Е.В., Христинина Е.В., 2018]; [Халиков А.Н., 2012]. 
аппарата формировать, в том числе следующие содержательные информационные блоки:

междисциплинарные типологии и классификации коррупционных преступлений и иных правонарушений применительно к корпоративному, государственному и некоммерческому сектору ${ }^{24}$;

уголовно-правовые, криминалистические и оперативно-розыскные характеристики коррупционных преступлений, иных правонарушений. Однако эти характеристики даются ни в коем случае не в плане «инструкций по совершению преступлений», а в контексте предупреждения добросовестных граждан о типичных попытках вовлечения их в преступную деятельность, об их негативных последствиях для этих лиц и всей организации;

описание и правовую оценку типичных коррупционных заблуждений уголовно-правового, криминалистического и оперативно-розыскного характера;

описание и правовую оценку коррупционных рисков, опять-таки междисциплинарного характера, включая необоснованные риски;

особенности деятельности правоохранительных органов по выявлению, расследованию и предупреждению коррупционных преступлений, иных мер по противодействию коррупции;

рекомендации, направленные на обеспечение сотрудничества между государственными органами, корпоративным и некоммерческим сектором в целях предупреждения и противодействия коррупции.

Все эти данные должны формулироваться не в традиционном (для ученых-юристов и правоприменителей), а в принципиально ином - просветительском формате, кратком и доступном корпоративному сектору и широким слоям населения. Необходимо подчеркнуть, что содержательная сторона антикоррупционного комплаенса должна учитывать и имеющуюся в отдельных случаях практику необоснованного уголовного преследования, незаконных оперативно-розыскных мероприятий, следственные и судебные ошибки, неправомерные действия конкурентов в рыночной среде, а также возможность клеветы со стороны недобросовестных лиц и средств массовой информации. Все эти риски актуальны как для менеджмента, так и для сотрудников компаний, и должны быть минимизированы ${ }^{25}$.

При этом авторы считают недопустимым в контексте антикоррупционного комплаенса прямо или косвенно содействовать созданию негативного имиджа правоохранительной системы государства. Ошибки и нарушения закона происходят в любой профессиональной деятельности. Факты незаконного и необоснованного привлечения к уголовной ответственности фи-

\footnotetext{
${ }^{24}$ Подробнее см.: [Казанцев Д.А., Ким Д.В., 2011].

${ }_{25}$ См., например: [Алистархов В., 2019: 89-96].
} 
зических лиц и компаний имеются в самых различных, в том числе в наиболее экономически развитых странах мира ${ }^{26}$.

Сотрудничество с правоохранительными и иными государственными органами является одним из элементов антикоррупционного комплаенса. Своевременное информирование правоохранительных органов, а также подразделений собственной безопасности различных организаций, может позволить защитить компанию от вымогательства и иных противоправных действий, предотвратить серьезные негативные последствия для конкретной компании, ее руководителей и сотрудников.

\section{Заключение}

Без содержательного наполнения и использования широкого междисциплинарного подхода антикоррупционный комплаенс останется комплаенсом на бумаге. По мнению авторов, настало время для создания научно обоснованной междисциплинарной концепции формирования и развития системы антикоррупционного комплаенса в Российской Федерации в рамках общей государственной антикоррупционной политики

В рамках концепции возможно решение следующих задач:

определение научных разработок и достижений из области криминалистики, криминологии, оперативно-розыскной деятельности, международного права, уголовного права и процесса, которые могут быть использованы в сфере антикоррупционного комплаенса;

анализ типологий коррупционных преступлений и правонарушений, совершаемых в корпоративном секторе;

определение круга коррупционных преступлений, на предупреждение и выявление которых должна быть направлена система мер, реализуемых в рамках антикоррупционного комплаенса;

описание уголовно-правовых и криминалистических характеристик таких преступлений;

разработка методик предупреждения и выявления коррупционных преступлений и правонарушений в корпоративном секторе в рамках антикоррупционного комплаенса;

определение эффективных методов проверки заявлений о возможных фактах совершения коррупционных преступлений и правонарушений и проведения внутренних расследований;

создание эффективных методик обучения и повышения квалификации специалистов в сфере антикоррупционного комплаенса;

${ }^{26}$ См., напр.: [Stinson P. et al, 2018: 310-331]. 
формирование методик обучения сотрудников компаний по вопросам антикоррупционного комплаенса.

Положения концепции могут использоваться в следующих целях:

определение путей дальнейшего развития антикоррупционного комплаенса; совершенствование правового регулирования;

подготовка международных и национальных руководств и рекомендаций по разработке, внедрению, оценке и мониторингу антикоррупционных комплаенс-программ;

создание новых и совершенствование существующих информационных технологий и программных продуктов в сфере антикоррупционного комплаенса;

разработка программ обучения и повышения квалификации специалистов в сфере антикоррупционного комплаенса;

подготовка методических рекомендаций и семинаров для судей по оценке реальности внедрения и эффективности антикоррупционных комплаенспрограмм при рассмотрении дел об административных правонарушениях по ст. 19.28 КоАП РФ;

подготовка методических рекомендаций для сотрудников правоохранительных органов, занимающихся вопросами борьбы с коррупцией, по вопросам взаимодействия с сотрудниками и структурными подразделениями компаний, отвечающими за антикоррупционный комплаенс;

разработка мер защиты российских компаний от необоснованного применения иностранного антикоррупционного законодательства

Положения концепции могут быть также использованы для разработки и внедрения стандартов и руководств по вопросам антикоррупционного комплаенса в рамках БРИКС и Евразийского экономического союза. Единые стандарты и руководства могут способствовать повышению прозрачности бизнеса и инвестиционной привлекательности как России, так и государств-партнеров.

\section{Б目 Библиография}

Алистархов В. Механизмы защиты предпринимателей на этапе до возбуждения уголовного дела // Административное право. 2019. № 2. С. 89-96.

Ашаффенбург Г. Преступление и борьба с ним: Уголовная психология для врачей, юристов и социологов. М.: ИНФРА-М, 2011. $241 \mathrm{c}$.

Бабаев М.М. Риски как компонент детерминационного комплекса преступности // Юридическая наука и практика: Вестник Нижегородской академии МВД России. 2018. N 1. C. $104-110$.

Бабаев М.М., Пудовочкин Ю.Е. Феномен риска в контексте профилактической политики (криминальная рискология) // Вестник СПбГУ. Право. 2019. Т. 10. Вып. 1. C. $136-148$. 
Баев О.Я. Основы методики уголовного преследования и профессиональной защиты от него: научно-практическое пособие (на примере уголовно-процессуального исследования должностных и служебных преступлений. М.: Эксмо, 2009. 400 с.

Башмаков И.С. Особенности первоначального этапа расследования коррупционных преступлений, совершаемых представителями органов местной власти. М.: Юрлитинформ, 2007. 152 с.

Гаухман Л.Д., Колодкин Л.М., Максимов С.В. (отв. ред.) Уголовное право: Часть общая. Часть особенная. М.: Юриспруденция, 1999. 784 с.

Герцензон А.А., Карпец И.И., Кудрявцев В.Н. (отв. ред.) Советская криминология. М.: Юрид. лит., 1966. 320 с.

Жалинский А.Э. Уголовное право в ожидании перемен: теоретико-инструментальный анализ. М.: Проспект, 2008. С. 242-249.

Казанцев Д.А., Ким Д.В. Проблемы криминалистической методики предварительного расследования и судебного разбирательства по делам о коммерческом подкупе. М.: Юрлитинформ, 2011. 160 с.

Кикоть В.Я., Лебедев С.Я., Румянцев Н.В. Предупреждение преступлений и административных правонарушений органами внутренних дел. М.: ЮНИТИ-ДАНА, 2015. 487 c.

Клейменов М.П. Криминологическое законодательство // Вестник Омского университета. Серия «Право». 2017. № 1. С. 179-184.

Крохина Ю.А. Юридическая сущность комплаенс-контроля в хозяйствующих субъектах с государственным участием // Юридическая наука. 2019. N 1. С. 35-39.

Марцев А.И. Уголовная ответственность как средство предупреждения преступлений. Омск: ВШМ МВД, 1980. 38 с.

Марцев А.И., Максимов С.В. Общее предупреждение преступлений и его эффективность. Томск: Изд-во Том. ун-та, 1989. 161 с.

Наумов С.Ю., Чаннов С.Е. (ред.) Комментарий к Федеральному закону от 25 декабря 2008 г. N 273-Ф3 «О противодействии коррупции» (постатейный). М.: Юстицинформ, 2009. 272 с.

Пудовочкин Ю.Е. Уголовное право: понятие, предмет, метод, система и задач / Энциклопедия уголовного права. Т. 1. Понятие уголовного права. СПБ.: Малинин, 2008. $734 \mathrm{c}$.

Смахтин Е.В., Христинина Е.В. Расследование получения взятки в системе высшего образования: криминалистические аспекты и некоторые вопросы квалификации. М.: Юрлитинформ, 2018. 208 с.

Сундуров Ф.Р., Тарханов И.А. (ред.) Уголовное право России. Общая часть. М.: Статут, 2009. 751 с.

Халиков А.Н. Должностные преступления: характеристика, расследование, предупреждение (криминалистический аспект). М.: Юрлитинформ, 2012. 312 с.

Щедрин Н.В. Основы общей теории предупреждения преступности. Красноярск: Изд. Краснояр. гос. ун-та, 1999. 58 с.

Щепельков В.Ф. Уголовный закон: преодоление противоречий и неполноты. М.: Юрлитинформ, 2003. 416 с.

Яни П.С., Прохоров Н.В. Антикоррупционный комплаенс в уголовно-правовой сфере: содержательный элемент // Российская юстиция. 2018. N 9. С. 54-57.

Moretti D. The use of intermediaries in corrupt deals. Lessons from the Petrobraz case for compliance officers. IACA research paper series, 2018, no 6. 
Stinson P. et al. To protect and collect: a nationwide study of profit-motivated police crime. Criminal Justice Studies, 2018, no 3, pp. 310-331.

\section{Pravo. Zhurnal Vysshey Shkoly Ekonomiki. 2020. No 4}

\section{On the Development of an Interdisciplinary Concept of Anti-Corruption Compliance in the Russian Federation}

\section{目Yury Garmaev}

Professor, Chair of Criminalistic and Criminal Procedure, Buryat State University, Doctor of Juridical Sciences. Address: 24 Smolin Str., Ulan-Ude 670000, Russian Federation. E-mail: garmaeff1@mail.ru

\section{目 Eduard Ivanov}

Professor, Department of International Law, Law Faculty, National Research University Higher School of Economics, Doctor of Juridical Sciences. Address: 20 Myasnitskaya Str., Moscow 101000, Russian Federation. E-mail: eaivanov@hse.ru

\section{凡目 Sergey Markuntsov}

Professor, Department of Court Proceedings and Criminal Law, Law Faculty, National Research University Higher School of Economics, Doctor of Juridical Sciences. Address: 20 Myasnitskaya Str., Moscow 101000, Russian Federation. E-mail: smarkuntsov@hse.ru

\section{瞋 Abstract}

Since the beginning of the 21 st century, companies from various parts of the world have been actively implementing an anti-corruption compliance. This process did not leave aside Russian, primarily large, enterprises. Under their influence, the implementation process gradually started in small and medium size enterprises that often act as suppliers or service providers. The role of anti-corruption compliance as a mechanism for protecting companies from corruption offences and other misconduct should be not underestimated. At the same time, the authors noted that many largest international enterprises that invest enormous funds in designing and implementing compliance programmes are not able to prevent wrongdoing of managers, employees and third parties. As a result, these enterprises pay huge penalties to resolve anti-corruption laws violations. Based on the results of the study, the authors come to the conclusion that anti-corruption compliance should not be limited to a set of management processes and formal standards. Anticorruption compliance programmes and training should have a meaningful filling aimed at preventing corruption offences. The article proposes and substantiates the idea of developing an interdisciplinary concept of anti-corruption compliance in the Russian Federation, based on the use of the achievements of the sciences of international law, criminal law, criminal procedure law, criminalistics and investigative activities. The authors propose own definition of the anti-corruption compliance and analyse main reasons for implementation of anti-corruption compliance in companies. Special attention is paid to distinctive features of legal regulation of the anti-corruption compliance in Russia and in foreign countries. The article contributes to the integration of main scientific definitions and concepts from criminal law and criminalistics, such as corruption crime, corruption 
offences and corruption risks into the concept of anti-corruption compliance system. According to the authors, interdisciplinary concept of anti-corruption compliance should create a solid basis for developing standards and recommendations for Russian companies and guidelines for judges and law enforcement officers. Many provisions could help in designing effective corporate policies and procedures, as well as training and professional development programmes on anti-corruption compliance. The concept can also be used for the development of anti-corruption cooperation within the BRICS and the Eurasian Economic Union.

\section{O-1国 Keywords}

anti-corruption; anti-corruption compliance; anti-corruption education; compliance; corporate sector; corruption crime; corruption offences; corruption prevention.

For citation: Garmaev Yu. P., Ivanov E.A., Markuntsov S.A. (2020) On the Development of Interdisciplinary Concept of Anti-Corruption Compliance in the Russian Federation. Pravo. Zhurnal Vysshey shkoly ekonomiki, no 4, pp. 106-128 (in Russian)

DOI: $10.17323 / 2072-8166.2020 .4 .106 .128$

\section{O-4国 References}

Alistarchov V. (2019) Protection mechanisms for entrepreneurs at the stage before initiating a criminal case. Administrativnoe pravo, no 2, pp. 89-96 (in Russian)

Aschaffenburg G. (2011) Crime and the fight against it: Criminal psychology for doctors, lawyers and sociologists. Moscow: INFRA-M, 241 p. (in Russian)

Babaev M.M. (2018) Risks as a component of the determination complex of crime. Legal Science and Practice. Vestnik Academii MVD, no 1, pp. 104-110 (in Russian)

Babaev M.M., Pudovochkin J.E. (2019) The phenomenon of risk in the context of preventive policy (criminal riskology). Vestnik Peterburgskogo universiteta, issue 1, pp. 136-148 (in Russian)

Baev O.J. (2009) Basics of methodology of criminal prosecution and professional protection from it. Moscow: Eksmo, 400 p. (in Russian)

Bashmakov I.S. (2007) The initial stage of investigation of corruption crimes committed by officials of local authorities. Moscow: Jurlitinform, 152 p. (in Russian)

Commentary to the Federal Law «On Combating Corruption" (2009) S.Y. Naumov, S.E. Channov, eds. Moscow: Justizinform, 272 p. (in Russian)

The Criminal Law: General Part. Special Part (1999) L.D. Gaukhman et al, eds. Moscow: Jurisprudencija, 784 p. (in Russian)

Kasantsev D.A., Kim D.V. (2011) Methods of preliminary investigation and trial in cases of commercial bribery. Moscow: Jurlitinform, 160 p. (in Russian)

Khalikov A.N. (2012) Official crimes: characteristics, investigation, prevention. Moscow: Jurlitinform, 312 p. (in Russian)

Kleymenov M.P. (2017) Criminological legislation. Vestnik Omskogo universiteta, no 1, pp. 179-184 (in Russian)

Krokhina Y.A. (2019) Legal essence of compliance control in business entities with state participation. Yuridicheskaya nauka, no 1, pp. 35-39 (in Russian)

Martsev A.I., Maximov S.V. (1989) General crime prevention and its effectiveness. Tomsk: University, 161 p. (in Russian) 
Martsev A.I. (1980) Criminal liability as a means of crime prevention. Omsk: Higher Police School, 38 p. (in Russian)

Moretti D. (2018) The use of intermediaries in corrupt deals. Lessons from the Petrobraz case for compliance officers. Available at: www.iaca.int/wwwtest/media/ attachments/2018/08/14/diogo_rf_paper_final_30_7_2018_format_edit.pdf (accessed: 30.07.2020)

Prevention of crimes and administrative offenses by the internal affairs bodies (2015) V.V. Kikot' et al, eds. Moscow: Juniti-Dana, 487 p. (in Russian)

Pudovochkin Y.E. (2008) Criminal law: concept, subject, method, system and tasks. In: Encyclopedia of Criminal Law. Vol. 1. Saint Petersburg: Malinin, 734 p. (in Russian)

Shchedrin N.V. (1999) Crime prevention theory. Krasnoyarsk: University, 58 p. (in Russian)

Shchepelkov V.F. (2003) Criminal law: overcoming contradictions and incompleteness. Moscow: Jurlitinform, 416 p. (in Russian)

Smakhtin E.V., Khristinina E.V. (2018) Investigation of Bribery in Higher Education: Forensic Aspects and Qualification Issues. Moscow: Jurlitinform, 208 p. (in Russian)

The Sovietcriminology (1966) Karpets I.I., KudryavtsevV.N., eds. Moscow: Juridicheskaya literatura, 320 p. (in Russian)

Stinson P. et al. (2018) To protect and collect: a nationwide study of profit-motivated police crime. Criminal Justice Studies, no 3, pp. 310-331.

Sundurov F.R. et al (2009) The Russian criminal law. General part. Moscow: Statut, 751 p. (in Russian)

Yani P.S., Prochorov N.V. (2018) Anti-corruption compliance in the criminal law sphere: a substantial element. Rossiyskaya justicia, no 9, pp. 54-57 (in Russian)

Zhalinskiy A.E. (2008) Criminal law risks: inevitable and overstated. Criminal law in anticipation of changes: theoretical and instrumental analysis. Moscow: Prospekt, pp. 242-249 (in Russian) 